\title{
Kamaya:

\section{Ajaran Agama Hindu Dalam Geguritan Candrabherawa Sebagai Penguatan Pendidikan Karakter}

\author{
Oleh: \\ I Wayan Agus Gunada \\ Institut Agama Hindu Negeri Gde Pudja Mataram \\ gunadastahngpmataram@gmail.com
}

\begin{tabular}{l}
\hline Keywords: \\
\hline Education; \\
Geguritan; \\
Candrabherawa; \\
Character \\
\hline
\end{tabular}

Kata Kunci:

Pendidikan;

Geguritan;

Candrabherawa;

Karakter

\begin{abstract}
Literary works are not merely a bouquet made in a short period of time, but are made with the various components and elements that make a literary work so much appreciated. Bali also in its development also has so many heritages of traditional and modern literary works but which generally become a historical heritage containing so many sacred Hindu religious teachings and still so highly developed in Bali is a rash. The Geguritan as mentioned by experts is a traditional literary heritage in which there are elements of Hindu religion that becomes one of the media in conveying Hindu teachings. One of the most well-known rash is Candrabherawa, composed and composed by I Ketut Ruma which tells the story of the War of Hastinapura with Dewantara due to differences in the implementation of religious teachings. So, of course, there are profound philosophical teachings. The study of the rash of Candrabherawa texts emphasizes the study of the value of Hindu teachings contained in the rash text. From the results of the study, that the text of Candrabherawa is the teaching of Tri Hita Karana, Tri Kaya Parisudha, Catur Marga, and chess clan that can be a reference and guidance in implementing the internalization of Susila value on the strengthening of character education for students by education actors in education institutions.
\end{abstract}

\footnotetext{
Abstrak

Karya sastra bukan hanya sekedar sebuah karangan yang dibuat dalam waktu singkat, namun dibuat dengan berbagai komponen serta unsur yang membuat sebuah karya sastra begitu dihargai. Bali dalam perkembangannya juga memiliki begitu banyak warisan karya sastra tradisional serta modern namun yang umumnya menjadi warisan sejarah yang mengandung begitu banyak ajaran-ajaran suci keagamaan Hindu dan masih begitu sangat berkembang di Bali adalah geguritan. Geguritan
} 
sebagaimana yang disebutkan oleh para ahli merupakan warisan sastra tradisional yang didalamnya terdapat unsur-unsur agama Hindu sehingga menjadi salah satu media dalam menyampaikan ajaran agama Hindu. Salah satu geguritan yang cukup dikenal adalah geguritan candrabherawa yang disusun dan dikarang oleh I Ketut Ruma yang menceritakan kisah peperangan Kerajaan Hastinapura dengan Dewantara akibat adanya perbedaan cara pandang dalam pelaksanaan ajaran agama. Sehingga tentu didalamnya terdapat ajaran-ajaran filosofis yang mendalam. Kajian teks geguritan candrabherawa menekankan kepada kajian nilai ajaran agama Hindu yang terkandung didalam teks geguritan tersebut. Dari hasil pengkajian didapatkan bahwa teks geguritan candrabherawa mengandung ajaran Tri Hita Karana, Tri Kaya Parisudha, Catur Varna dan Catur Marga yang dapat menjadi acuan dan pedoman dalam melaksanakan internalisasi Nilai Susila pada proses penguatan pendidikan karakter bagi peserta didik oleh pelaku-pelaku pendidikan dalam lembaga Pendidikan.

\section{Pendahuluan}

Manusia adalah makhluk ciptaan Tuhan yang dibekali dengan akal dan pikiran. Manusia merupakan ciptaan Tuhan Yang Maha esa yang memiliki derajat paling tinggi di antara ciptaannya yang lain (Sumantri, 2015). Manusia merupakan makhluk hidup yang berakal, mengapa karena dalam menjalankan segala segi kehidupannya maka akal dan pikiran menjadi tumpuan utama sehingga apa yang dilakukan dalam menjalankan kehidupannya akan dapat memilih mana yang baik dan mana yang tidak baik. Akal dan pikiran inilah yang menyaring sehingga manusia dapat memilih apa yang akan dia lakukan. Akal dan pikiran manusia tentu dalam prosesnya perlu diasah dan dibentuk sesuai dengan perkembangan manusia tersebut. Selain dengan pengalaman hidupnya yang membentuk kepribadian sehingga pola pikirnya dapat terasah dan berkembang, maka pendidikan juga menjadi semacam faktor penting dalam proses pengembangan kemampuan manusia, utamanya pengembangan kecerdasan intelektual, emosional dan spiritual. Pendidikan begitu penting, bukan hanya sekedar proses belajar mengajar semata namun esensi yang terkandung dalam makna pendidikan adalah proses pengembangan diri.

Pendidikan adalah segala daya dan upaya dari semua usaha untuk membuat masyarakat dapat mengembangkan potensi peserta didik (Rini, 2010). Mengacu kepada apa yang tertuang dalam Undang-undang No. 20 Tahun 2003 tentang sistem Pendidikan 
Nasional disebutkan bahwa Pendidikan merupakan usa sadar dan terencana untuk mewujudkan suasana belajar dan proses pembelajaran agar peserta didik secara aktif mengembangkan potensi dirinya untuk memiliki kekuaran spiritual keagamaan, pengendalian diri, keporibadian, kecerdasan, akhlak mulia, serta keterampilan yang diperlukan dirinya, masyarakat, bangsa dan negara. Maka pendidikan bukan hanya terfokus pada proses belajar dan mengajar semata, tetapi sebagaimana yang sudah dijelaskan maka pendidikan adalah proses pengembangan diri, yaitu pengembangan potensi baik itu potensi intelektual dan lebih dalam adalah karakter.

Pendidikan karakter secara filosofis dapat dimaknai sebagai dua hal yang saling berkaitan yaitu pendidikan dan karakter. Najib Sulhan (dalam Jalil, 2016) menyebutkan bahawa aksioma yang tidak bisa terbantahkan adalah pendidikan bahwa pendidikan merupakan pilar bangsa. Maka pendidikan adalah suatu proses yang begitu penting karena pendidikan merupakan suatu pondasi dasar dan penyangga yang nantinya untuk dapat membantu dan mengembangkan potensi dan peradaban bangsa. karakter adalah nilai-nilai yang khas baik yang terpatri dalam diri dan terwujud dalam perilaku (Setiawati, 2017). Maka dapat disederhanakan bahwa pendidikan dan karakter adalah suatu hal yang saling tertaut dan terkait dimana muara dari pendidikan adalah karakter dan hulu dari karakter adalah proses pendidikan yang koheren dan komprehensif.

Manusia sebagai pelaku dari pendidikan dan subjek dari proses pendidikan karakter tentu harus memahami bahwa pendidikan, karakter selalu terkait dengan lingkup budaya dan kebudayaan dimana manusia tersebut hidup. Pada dasarnya suatu kelompok masyarakat atau bangsa memiliki pandangan hidup yang diwarisinya dari zaman ke zaman dan merupakan nilai-nilai yang diyakini kebenarannya dimana pendidikan dalam hal ini prosesnya berusaha untuk mewariskan pandangan-pandangan dan keyakinan yang bermanfaat kepada generasi selanjutnya(Normina, 2017). Sehingga secara teoritis dapat disimpulkan bahwa kebudayaan dalam hal ini budaya merupakan suatu pandangan, perilaku yang memiliki nilai serta legacy yang sangat penting dimana pendidikan berusaha untuk mentranformasi nilai-nilai yang bermanfaat tersebut agar dapat diwariskan dan berkembang pada generasi-generasi selanjutnya.

Pendidikan karakter bagian dari proses legacy kebudayaan ini secara empiris di Bali dengan keyakinan mayoritas warganya beragama Hindu dilakukan dengan tetap memegang teguh ajaran agama Hindu dalam kehidupan sehari-harinya. Ada semacam kaitan antara perilaku umat Hindu, proses pendidikan dan karakter Hindu yang ingin 
diwujudkan dalam pendidikan di Bali. Perilaku umat yang sering digenarilisir dan disebut dengan etika menurut (Madja, 2018) memiliki makna pandangan terkait mana yang dianggap sebagai perbuatan baik dan mana perbuatan yang jahat. Sehingga relasi antara perilaku dengan agama Hindu adalah bagaimana ajaran agama Hindu yang begitu sarat akan nilai estetika dan etika menjadi indikator serta menjadi pedoman dan melalui proses pendidikan inilah kemudian karakter manusia Hindu dapat terwujud. Proses pendidikan karakter yang menjadikan budaya sebagai pedomana pelaksanaan di Bali salah satunya melalui kegiatan Dharma Gita. Dharma Gita sebagai sebuah proses perkembangan budaya Hindu yang perlu dikembangkan untuk meningkatkan kualitas kehidupan beragama di kalangan umat Hindu dan hakekat dari dharma gita sebagai nyanyian suci maka unsur estetika merupakan hal yang esensial (Putu Sari, 2019). Ini menyimpulkan bahwa dharma gita sebagai sebuah legacy budaya bali dan budaya Hindu bukan hanya sekedar proses berkesenian yang hanya bermuara pada sisi estetika namun dalam pelaksanaannya esensi peningkatan kualitas sradha dan bhakti umat Hindu juga menjadi tujuan utama dharma gita tersebut.

Salah satu bagian dari dharma gita adalah geguritan. Geguritan adalah sebuah karya sastra yang dinyanyikan dimana geguritan diikat oleh aturan-aturan yaitu pada lingsa dalam pupuh-pupuh yang membentuk struktur geguritan. Geguritan candrabherawa sebagai salah satu teks geguritan merupakan salah satu karya sastra yang cukup lama yang dikarang oleh I Ketut Ruma yang disadur melalui lontar Purwwagama Sasana. Secara Pragmatis penelitian ini berfokus kepada pengkajian teks geguritan candrabherawa yang ingin menggali nilai-nilai pendidikan karakter berdasarkan ajaran agama Hindu yang terdapat didalamnya yang nantinya nilai-nilai karakter ini terkait dengan karakter sebagaimana definisi pendidikan dalam Sistem Pendidikan Nasional. Tujuannya adalah bagaimana ajaran agama Hindu sebagai sebuah media dan sumber serta acuan nilai-nilai pendidikan karakter tersebut nantinya dapat diimplementasikan dan diinternalisasikan melalui proses pendidikan, baik itu pendidikan formal, nonformal dan informal mengingat nilai-nilai budaya melalui warisan-warisan kebudayaan pada era ini seperti dimarginalkan sehingga proses pendidikan yang terkesan parsial, sehingga diharapkan dengan membangkitkan kembali nilai-nilai pendidikan esensial yang terdapat dalam warisan budaya khususnya dalam dharmagita yaitu geguritan candrabherawa dapat menjadi pedoman dalam beretika bagi umat Hindu khususnya pengembangan pendidikan karakter. 


\section{Metode}

Penelitian ini dengan fokus mengkaji geguritan candrabherawa menggunakan pendekatan kualitatif dengan menfokuskan kepada studi fenomenologi. Pemilihan penelitian kualitatif dengan pendekatan fenomenologi ini karena berkaitan dengan permasalahan dan pengkajian terkait dengan mulai adanya semacam fenomena demoralisasi serta degradasi moral yang terjadi pada anak-anak usia sekolah yang tentu harus menjadi perhatian sehingga ajaran agama Hindu sebagai ajaran suci dalam geguritan candrabherawa menjadi suatu nilai penting sebagai sarana dan acuan penguatan pendidikan karakter sehingga data didapat yang tentu dalam pemaparan analisisnya dilakukan melalui mendeskripsikan dan menarasikan data tersebut. Dalam penelitian ini data digali melalui dua sumber data yaitu sumber data primer yaitu data yang didapatkan melalui pengkajian objek penelitian yaitu geguritan candrabherawa dan data sekunder melalui studi pustaka terkait hasil-hasil penelitian yang terkait dengan penelitian ini dan pustaka-pustaka yang relevan yang menunjang penelitian ini. Untuk instrumen penelitian maka peneliti bertindak sebagai instrumen kunci yang mengkaji serta menginterpretasikan data terkait geguritan candrabherawa tersebut. Dalam memverifikasi keabsahan data maka peneliti menggunakan model Miles dan Huberman, dimana data yang didapat direduksi melalui mana data yang relevan dengan penelitian dan mana yang tidak, data yang sudah dipilah-pilah kemudian disajikan melalui pola-pola sehingga didapatkan data yang terkait dan sesuai dengan permasalahan serta memverifikasi dan menarik kesimpulan atas data tersebut. Untuk mengecek kevalidan data kembali melalui metode trianggulasi data yaitu mengecek dan memadukan serta membandingkan kembali data yang didapat dari sumber data dengan teknik pengumpulan data yaitu observasi dan studi pustaka dan dokumen sehingga mendapatkan data yang benar-benar valid terkait nilai-nilai ajaran agama Hindu yang terkandung dalam geguritan candrabherawa yang relevan dengan pendidikan karakter menurut definisi pendidikan dalam sistem pendidikan nasional yang diharapkan dapat menjadi pedoman internalisasi nilai untuk mengembangkan karakter peserta didik yang daiwi sampad.

\section{Hasil dan Pembahasan}

Pendidikan karakter dewasa ini memperoleh posisi yang cukup penting dalam proses pendidikan di Indonesia, adanya semacam anggapan bahwa terjadi degradasi 
moral yang terjadi pada masyarakat di Indonesia bahkan pada usia sekolah menjadi semacam indikator adanya demoralisasi tersebut. Anggapan semacam ini nyatanya bukan hanya sekedar isapan jempol semata, data UNICEF tahun 2016 menunjukkan bahwa kekerasan pada sesama remaja di Indonesia diperkirakan mencapai 50 persen. Sedangkan dilansir dari data Kementerian Kesehatan RI 2017, terdapat 3,8 persen pelajar dan mahasiswa yang menyatakan pernah menyalahgunakan narkotika dan obat berbahaya". Data ini menunjukkan bahwa angka 50\% tentu bukan angka yang kecil jika dirasiokan dari total jumlah remaja yang ada di Indonesia, ini tentu menjadi catatan buruk dan tentu tamparan yang sangat keras bagi Indonesia (UGM, 2020) .

Pada media-media juga sering kali termuat berita-berita yang didalamnya terdapat kekerasan-kekerasan yang dilakukan oleh remaja, yang terbaru sekarang ini sedang menjadi perbincangan adalah terkait kasus pembunuhan bayi oleh remaja yang dilakukan karena terinspirasi dari film. Fenomena "Motif siswi SMP berinisial NF (15) tega menghabisi nyawa teman rumahnya dengan keji akhirnya terungkap. Ia membunuh APA, bayi lima tahun (balita) yang tewas ditenggelamkan NF (15 tahun), di kawasan Sawah Besar, Jakarta Pusat, dua hari lalu. Usai membunuh korban, NF kemudian menyimpan mayat balita itu di dalam lemarinya semalaman" (Tribunnews.com, 2020). Dari berita tersebut dapat diambil suatu kesimpulan bahwa telah terjadi suatu degradasi moral dan demoralisasi yang terjadi di Indonesia. Yang menjadi pertanyaan kemudian apa yang menyebabkan hal demikian terjadi, maka pendidikan sebagai sebuah institusi wajib menjadi penangkal dan tameng sehingga perilaku-perilaku semacam tersebut dapat dicegah.

Penelitian ini kemudian mencoba untuk mengkaji serta membedah nilai-nilai suci ajaran Hindu yang terkandung didalam geguritan candrabherawa. Geguritan bukan hanya sebuah karya sastra, namun dalam proses aplikasinya sebagai bagian dari pelaksanaan dharmagita yaitu nyanyian dharma adalah sebuah proses internalisasi nilai atau ajaran agama yang dilakukan melalui media seni yang berimbas pada peningkatan sradha dan bhakti umat Hindu. Sehingga tentu nilai yang terkandung didalam geguritan ini diharapkan dapat menjadi pedoman dalam peningkatan pendidikan karakter melalui proses pendidikan keagamaan. Hal ini sejalan dengan usaha Kementerian Agama melalui PMA No. 2 Tahun 2020 tentang Penyelenggaraan Penguatan Pendidikan Karakter. Maka penelitian ini berusaha untuk ikut menggali nilai-nilai lokal genius, nilai-nilai budaya serta nilai-nilai keagamaan sebagai bentuk pedoman sehingga penguatan pendidikan 
karakter melalui internalisasi nilai-nilai dapat dilakukan dan berhasil sesuai harapan yang diinginkan.

Berdasarkan hasil pengkajian terhadap teks geguritan candrabherawa maka ditemukan beberapa ajaran agama Hindu yang dapat dijadikan sebagai nilai-nilai yang relevan dalam proses penguatan pendidikan karakter sesuai definisi pendidikan pada Sistem Pendidikan Nasional. Secara singkat dapat diuraikan bahwa dalam geguritan candrabherawa mengisahkan peperangan yang terjadi antara kerajaan Hastinapura dengan kerajaan Dewantara akibat dari adanya perbedaan dan kesalahpahaman kedua belah pihak dalam menjalankan ajaran dharma atau ajaran agama sehingga terjadilah perang namun berakhir dengan damai karena adanya kesadaran bahwa proses pelaksanaan ajaran agama yang dilakukan oleh setiap orang tentu sesuai dengan kualitas spiritual dari seseorang sehingga yang harus dilakukan adalah peningkatan pemahaman dalam menginterpretasikan ajaran agama tersebut. Maka dari hasil pengkajian geguritan candra bherawa tersebut didapatkan hasil beserta pembahasan sebagai berikut :

\section{Nilai Karakter Akhlak Mulia dalam ajaran Tri Hita Karana dan Tri Kaya Parisudha}

Pada penelitian penulis (2020) sebelumnya terkait pula dengan pendidikan karakter yang mengacu kepada nilai-nilai pendidikan karakter menyebutkan bahwa proses penguatan pendidikan karakter tidak hanya bertumpu kepada bagaimana peran guru sebagai subjek pendidik dalam lembaga pendidikan formal, namun lebih jauh adalah harus adanya interaksi dan afilisiasi yang baik antara keluarga dan masyarakat sebagai lembaga pendidikan sehingga nantinya ajaran-ajaran suci Hindu dapat diimplementasikan dalam proses internalisasi penguatan karakter (Gunada, 2020). Sehingga ajaran agama Hindu yang dikaji tidak hanya sekedar kajian dalam teks, namun harus dapat diimplementasikan oleh seluruh lembaga pendidikan utamanya keluarga, guru dan masyarakat. Ajaran agama hindu yang terdapat dalam teks geguritan candrabherawa adalah ajaran Tri Hita Karana dan Tri Kaya Parisudha. Tri Hita Karana berasal dari unsur kata "Tri" yang berarti Tiga, "Hita" bermakna kebahagiaan dan "karana" yang berarti penyebab. Sehingga secara sederhana Tri Hita Karana dapat dimaknai sebagai Tiga Unsur yang menyebabkan kebahagiaan kepada manusia, kebahagian ini bukan hanya kebahagaian jasmani namun juga kebahagian rohani, yaitu melalui parhyangan, pawongan dan palemahan yaitu penghormatan kepada Tuhan sebagai Pencipta alam 
semesta, penghormatan kepada sesama manusia sebagai ciptaan Tuhan dan penghormatan kepada alam semesta sebagai bagian dari Tuhan.

Tri Kaya Parisudha sebagai konsep ajaran agama Hindu memiliki makna tiga unsur atau tiga perbuatan yang menyucikan keadaan manusia, tiga perbuatan ini akan membawa dampak yang baik bila dilakukan dengan kesungguhan hati yaitu Kayika Parisudha yaitu Perbuatan yang baik, Wachika Parisuda yaitu perkataan yang baik dan Manachika Parisudha yaitu berpikir yang baik, sehingga tiga perbuatan ini merupakan sebuah bagian yang penting yang dalam prosesnya adalah saling melengkapi. Ajaran Tri Kaya Parisudha merupakan bagian dari sebuah acuan perbuatan yang nantinya akan membeuk tingkah laku yang baik dimana relevansinya pada proses pembelajaran PKn (Pendidikan Kewarganegaraan) maka ajara Tri Kaya Parisudha akan bermuara pada pembentukan nilai, moral serta sikap yang baik(Ganesha, 2014). Dalam teks geguritan candrabherawa maka ajaran Tri Kaya Parisudha dan Tri Hita Karana tertuang dalam kutipan teks berikut :

Yayi Brahmä apa krana, tan hana sanggar palinggih, gěnah mangarccana déwa, Aryya Brahmä mañahurin, kènè dèwa apang huning, sangkaning Ida Sang Prabhu, mangamběkang Aji Pégat, kèwala dharmma piněrih, tan ngawangun, sanggar děngěn kabuyutan (Geguritan candrabherawa, pupuh sinom, pada : 27, hal 9).

Terjemahannya :

"Wahai sang arya Brahma apa penyebab, tidak ada satupun sanggar pelinggih, tempat menstahanakan dewa, aryya brahma menjawab, begini Bhima agar tahu, penyebab sang raja, menjalankan ajaran keTuhanan, namun ajaran dharma agama yang diutamakan, tidak membangun tempat suci, sanggar dan sebagainya.

Wantah ring angga sarira, Hyang Suksma kahastuti, linggayang jro ning trikaya, bantěnin ban solah lewih, miwah rawos sanè běcik, pakayunanè rahayu, hěnto käturang ring ida, sat waluya bantèn suci, kèto tuhu, jagatè di Dèwantara (Geguritan candrabherawa, pupuh sinom, pada : 28, hal 9).

Terjemahannya :

Hanya di dalam badan sendiri, Tuhan pencipta berstahana, stahanakan dengan menjalankan ajaran Tri Kaya, wakili dengan perbuatan yang baik, dan berbicara yang baik, pemikiran yang baik, itu yang dihaturkan kepada Tuhan, sudah bagaikan banten yang suci, begitulah adanya kerajaan Dewantara.

To awanan tan sangkaning saja tatas, ring daging kärmma sanyaşin, bantas bisa ñěmbah, tan tatas mulaning sembah, tungtung sěmbah tan kuningin, miwah sang aněmbah, talěr tan kahuningin (Geguritan candrabherawa, pupuh durma, pada : 6, hal 13).

Terjemahannya : 
Itulah sebabnya sehingga harus benar-benar tahu, dari isinya Karma Marga, sebatas bisa menyembah tidak tahu siapa yang harus disembah, cara menyembah tidak diketahui, dengan yang disembah, juga tidak diketahui.

Yan kèwala bisanè bantas mañembah, sūkşman ña tan kuningin, gahènang pralingga, gahènang bantěn pingitang, sungsung gahènang palinggih, mèru paryangan, to ngawè byapara paling (Geguritan candrabherawa, pupuh durma, pada : 7, hal 13).

Terjemahannya :

Kalau hanya sekedar menyembah, intinya tidak diketahui, buatkan pralingga (simbol suci), buatkan banten disakralkan, disungsung buatkan pelinggih, parhyangan meru, itu yang membuat kebingungan.

Twara ada suměkěn ngělah panawang, dèwa di sanggar malinggih, mèru kabuyutan, sunya suhung sujatinña, twara tahèn jerit-jěrit, nagihang bantěn, tong ada Dèwa ñakitin (Geguritan candrabherawa, pupuh durma, pada : 8, hal 13).

Terjemahannya :

Tidak ada yang benar-benar mempunyai pengetahuan, dewa disanggar distahanakan, alam semesta kosong sepi sejatinya, tidak pernah berteriak-teriak, meminta banten, tidak ada dewa yang menyakiti.

Yaning dini jagatè di Dèwantara, tan pisan ngamargginin, macaru mabantěn, yadyapi mayajña-yajña, ěnto arccanè liyatin, tilěh rūpanña, yadyan jā tan bantěnin. (Geguritan candrabherawa, pupuh durma, pada: 9, hal 14).

Terjemahannya :

Kalau disini di jagat dewantara, tidak sekalipun menjalankan, mecaru mebanten, bahkan beryajna, itu arca lihat, tetap bentuknya, walaupun tidak diberikan banten.

Yadyastun ada anak mangentungang, sinah twara ñakitin, manahè ngawinang, ngawè panampènè bhina, ngawè takut ngawè bani, manah wwang müdha, papak papak karyyanin (Geguritan candrabherawa, pupuh durma, pada : 10, hal 14).

Terjemahannya :

Walaupun ada yang membuang, tidak akan menyakiti, pikiran yang menyebabkan, membuat takut membuat berani, pikiran dengan perasaan, baikbaik lah diperbuat.

Dwaning ada jalaran bhakti ring dewa, hasthawa rahina wěngi, ring angga sarira, linggayang jroning trikaya, kaya wäk manah hapikin, hěnto pidabdab, pangubhakti pinih lewih (Geguritan candrabherawa, pupuh durma, pada : 11, hal 14).

Terjemahannya :

Sehingga ada yang namanya jalan bhakti kepada Tuhan, berdoa pada malam hari, di dalam diri sendiri dudukkan ajaran Tri Kaya, perbuatan perkataan dan pikiran, itulah yang dilakukan, sebagai bentuk bakti yang paling baik.

Kutipan teks geguritan candrabherawa diatas secara inplisit menjelaskan bahwa dalam kewajiban sebagai manusia adalah bagaimana kemudian mensthanakan Tuhan 
sebagai pencipta alam semesta beserta isinya bukan hanya sekedar dengan membuat simbol-simbol namun lebh dalam adalah bagaimana manusia memperlakukan alam semesta itu sendiri sebagai bagian dari Tuhan. Hal ini seringkali terjadi dimana begitu banyak proses keagamaan dilakukan melalui upacara-upacara yang ditujukan kepada Tuhan namun realitanya kemudia penghormatan kepada Tuhan tidak serta merta dilakukan pula kepada ciptaannya, manusia dengan manusia saling bermusuhan, membuang sampah sembarangan sehingga merusak lingkungan dan seringkali terjadi penyiksaan terhadap hewan tentu menjadi semacam kontradiksi dan ironi. Sehingga dalam teks geguritan candrabherawa disebutkan bahwa menstahanakan dan menghormati Tuhan adalah dengan melaksanakan ajaran Tri Hita Karana sebagai sebuah simbol banten atau sarana pemujaan. Dalam kitab sarasamusccaya Sloka 14 disebutkan :

dharma eva plavo nanyah svargam samabhivāňchatam, sa ca naurvanisjasstatam jaladheh pāramicchatah.

ikang dharma ngaranya, henuning mara ring svarga ika kadi gatining parahu, an henuning banyaga netasing tasik.

Yang artinya yang disebut dengan dharma, adalah merupakan jalan untuk pergi ke surga, sebagai halnya perahu, sesungguhnya adalah merupakan alat bagi orang dagang atau nelayan untuk mengarungi lautan. Sebagaimana yang tertuang dalam kutipan sloka diatas dapat diartikan bahwa dharma sebagai sebuah ajaran agama, tapi dharma adalah sebagai sebuah kewajiban, maka kewajiban menjalankan dharma salah satunya dengan melaksanakan perbuatan Subha Karma, karena dengan perbuatan baiklah maka manusia akan mendapatkan kebahagiaan di dunia ini.

Ajaran agama hindu sebagai gambaran ajaran Tri Hita Karana dan Tri Kaya Parisudha yang terkait dengan teks tersebut diatas dalam penguatan pendidikan karakter dapat dijadikan sebagai acuan dan landasan beretika yang dapat dilakukan dan disasarkan kepada anak didik. Demoralisasi yang terjadi kini cenderung mengarah kepada mulai hilangnya kesadaran untuk bertingkah laku yang baik pada diri siswa, mulai dari perbuatan-perbuatan dalam bentuk vandalisme, perkataan-perkataan sarkastik dan pelanggaran hukum ini menjadi suatu indikator bahwa ada suatu masalah yang terjadi. Sehingga apa yang menyebabkan hal tersebut, seringkali terjadi karena anak didik mencontoh apa yang dilakukan oleh orang dewasa, sehingga disinilah peran lembaga pendidikan keluarga, guru dan masyarakat mengambil peran, yang dilakukan adalah bukan saja mentransfer ilmu dan nilai-nilai ajaran hindu tersebut namun lebih penting mentranformasi nilai, sehingga salah satu jalan adalah menjadi role model bagaimana 
pengembangan karakter spiritual keagamaan dan akhlak mulia dilakukan sehingga dengan menjadi model atau contoh maka anak didik akan mengimitasi tingkah laku dari contoh yang dirinya lihat dalam dirinya.

\section{Nilai Karakter Kepribadian melalui pemahaman ajaran Catur Varna}

Sudarsini (2018) menyebutkan bahwa konsep Catur Varna yang disusun oleh para Maha Rsi merupakan ajaran suci yang terkandung didalam kitab suci Weda yang bukan bertujuan untuk membeda-bedakan dan membandingan suatu golongan dengan golongan lain namun istilah varna muncul untuk memberikan gambaran manusia berdasarkan profesi dan tingkat kemampuan yang dimilikinya (Sudarsini, 2018). Konsep varna sendiri berbeda dengan kasta, dimana jika kasta lebih kepada hak dan kedudukan berdasarkan geneologi atau keturunan, varna lebih kepada profesi dan kompetensi manusia, dimana dalam konsep varna manusia diberikan kebebasan untuk semakin mengisi diri sehingga memiliki kompetensi yang lebih unggul, namun konsep varna adalah sebuah proses tahapan untuk lebih mendekatkan diri kepada Tuhan sehingga ketika manusia nantinya paham hakekatnya sebagai ciptaan Tuhan maka konsep varna harus ditinggalkan sebagai sebuah pembebasan belenggu ketidaktahuan.

Dalam teks geguritan candrabherawa maka karakter kepribadian berdasarkan pemahaman ajaran Catur Varna tertuang dalam kutipan teks sebagai berikut :

Sang Bhimasèna ñujutang, bingung kayunè nampènin, awangsa apa sujatinña, parāryya sambatang jani, twara ada kapanggihin, yan ring catur-jana mungguh, apa kè Brāhmaña Satriya, Wèsya Sudra wangsan cahi, Aryya Wisnu, raris gélis midārthayang (Geguritan candrabherawa, pupuh sinom, pada : 18, hal 6).

Terjemahannya :

Sang Bhimasena tertegun, bingung hatinya mendengar, wangsa apa sebenarnya, para arya katakanlah sekarang, tidak ada pernah ditemui, di empat jenis wangsa, Brahmana, Satriya, Wesya maupun Sudra Wangsa Kamu, Arya Wisnu, lalu dengan segera memberitahu.

Udhūh Mahārāja Bhīma, kènè pidabdabè dini, yan buwat i catūr warnna, mula ada saking rihin, nè mādan Brāhmana jati, sang wěruh ring tatwa tutur, katatwan kabrähmañan, püja mantra pangastuti, tělěb kukuh, ngamarggyang kasuśilan (Geguritan candrabherawa, pupuh sinom, pada: 19, hal 6).

Terjemahannya :

Wahai Maharaja Bhima, beginilah adanya disini, kalau untuk empat warna, memang sudah ada sejak dahulu, yang bernama brahmana sebenarnya, yang tahu tentang ajaran filsafat (tattwa), esensi menjadi seorang brahmana, puja serta mantra yang mendalam, dengan teguh menjalankan etika yang baik. 
Pidabdab sang mraga Kşatriya, rāja śasaņa känütin, catür näya haştèśwaryya, puruşa tan papakèring, swadharmman Sang Wèsya mangkin, pagěh makāryya mamacul, nabdab kalanduhan jagat, myara kěbo miwah sampi, śudra iku, malayar madadagangan (Geguritan candrabherawa, pupuh sinom, pada : 20, hal 7)

Terjemahannya :

Kewajiban adanya seorang yang berstatus Ksatirya, kewajiban seorang raja yang wajib menjadi pedoman, empat kewajiban ajaran asta aiswarya, kewajiban dan hak, kewajiban seorang Wesya sekarang, teguh bekerja bertani, membuat kesejahteraan dunia, memelihara kerbau dengan sapi, sudra itu, berlayar berdagang.

Nānghing yan indik kawangsan, Brahmā Wisnu karwa kami, nganutin mantri śasana, kabawos satriya lěwih, tan manut śasanan ratu, tan kşatriya kabawosang, Brāhmaña tan dwijāti, tan kapatut, kabawosang Brāhmaņa (Geguritan candrabherawa, pupuh sinom, pada : 21 hal 7)

Terjemahannya :

Namun jika terkait dengan wangsa, Brahma Wisnu kami, berpedoman pada tugas seorang mentri, disebut kesatria utama, tidak berpedoman pada tugas seorang raja, bukan kesatria disebut, Brahmana yang tidak melaksanakan Dwijati, tidak patut, disebut Brahmana.

Sapunika wangsa Wèsya, tan huning hamongan tani, boya wèsya kabawosang, yan padè sang Sudra lèngit, raris surud ngalèmpasin, sakadi hamongan ipun boya Šudra kabawosang, sakadi ucaping haji, kèto tuhu, yan manut panampèn kakā (Geguritan candrabherawa, pupuh sinom, pada : 22, hal 7).

Terjemahannya :

Begitu juga wangsa wesya, tidak mengerti pengetahuan bertani, bukan wesya namanya, begitu pula seorang sudra malas, lalu berhenti dan menolak, bagaikan seorang pemalas dia bukan sudra disebut, bagaikan perkataan, begitu dulu, kalau menurut pemahaman ku.

Kutipan teks diatas dapat disimpulkan bahwa dalam konsep Catur Varna dikenal yaitu Brahmana, Ksatriya, Wesya dan Sudra. Keempat konsep ini dalam teks geguritan candrabherawa menekankan kepada pengetahuan akan esensi warna sehingga setiap warna memiliki peran dan kewajibannya. Sehingga melalui pemahaman akan dirinya maka seseorang akan tahu pada warna apa dirinya berada, namun konsep ini memberikan kebebasan kepada setiap individu untuk meningkatkan kemampuannya sehingga pada satu warna seseorang bisa berada pada warna yang lain. Pada hakekatnya konsep warna bertujuan agar manusia mengenal dirinya, mengenal pribadinya, sehingga ketika individu sudah mengenali dirinya maka dia akan dapat menjalankan kewajibannya sehingga tidak terjadinya bias akan pemahaman hakekat dirinya lahir ke dunia, sehingga tujuan akhir dari konsep Catur Varna adalah pembebasan dirinya untuk dapat bersatu dengan Tuhan melalui ajaran-ajaran suci Hindu. Terkadang karena adanya pembiasan antara warna dan 
kasta sering kali memberikan miss pemahaman yang seringkali menimbulkan konflik. Individu merasa lahir dari kalangan yang dianggap kelahiran utama sehingga merasa diri paling besar dan mulia dan merendahkan orang lain yang tidak lahir dalam garis keturunannya. Tentu hal ini menjadi ironi dan dilema sehingga pembentukan karakter kepribadian wajib diperkuat melalui konsep-konsep implemntasi ajaran suci.

Pada proses ini, maka penguatan karakter kepribadian dengan internalisasi ajaran Catur Varna dapat dilakukan dengan berbagai jalan yaitu lembaga pendidikan memberikan pemahaman hakekat peserta didik dalam menjalankan proses pendidikan. Dewasa ini seringsekali terjadinya miss pemahaman proses pendidikan, sebagian pelaku pendidikan baik itu guru maupun peserta didik hanya memahami pendidikan adalah suatu proses dimana lulusan yang dihasilkan untuk siap bekerja, sehingga pendidikan hanya condong kepada penyiapan tenaga kerja semata. Ini tentu ironi, karena tidak sesuai dengan konsep pendidikan secara murni. Pendidikan memiliki pengertian sebagai proses pembentukan Kepribadian, hal ini didasarkan bahwa pendidikan dilakukan melalui proses yang sistematis dan sistemik dimana dalam proses pembentukan dilakukan oleh orang dewasa kepada pribadi yang belum dewasa dan oleh orang dewasa atas usaha sendiri (Husamah, 2015). Maka dapat diartikan bahwa pendidikan memiliki makna sebagai proses pembentukan Kepribadian yang menyiapkan dirinya untuk siap dalam menjalani kehidupan, kepribadian disini didasarkan agar manusia tahu esensinya sebagai manusia sehingga dapat melaksanakan kehidupannya dengan tingkah laku yang baik.

Sehingga sebagai sebuah lembaga pendidikan, penguatan karakter peserta didik tidak hanya mengarahkan kepada bagaimana lulusan tersebut siap bersaing dalam dunia kerja namun lebih dalam adalah bagaimana ketika peserta didik bersaing dalam dunia kerja mereka memiliki pribadi yang baik, sehingga siap bersaing dengan sehat. Disinilah peran lembaga pendidikan, baik sekolah, keluarga dan masyarakat untuk terus memberikan pemahaman, pengertian dan pengetahuan akan hal tersebut. Sehingga konsep warna dalam kaitannya dengan pembentukan kepribadian berfungsi sebagai pemahaman kesadaran akan hakekat manusia itu sendiri, sehingga dengan kesadaran akan keberadaan dirinya dalam warna sesuai tingkat kemampuannya maka akan terus memberikan kesadaran untuk selalu meningkatkan dirinya sehingga kelak dapat membebaskan diri untuk bersatu kepada Tuhan. 


\section{Nilai Karakter Kecerdasan Spiritual Keagamaan melalui ajaran Catur Marga}

Utami (2018) menyebutkan bahwa pendidikan pada hakikatnya merupakan proses memanusiakan manusia, dalam prosesnya pendidikan diharapkan membentuk manusia yang sejati, kesejatian ini ditunjukkan dengan karakter. Apa yang dijelaskan oleh Utami menyimpulkan bahwa pendidikan pada hakekatnya adalah bertujuan untuk membentuk karakter, bukan hanya sebatas pada pengembangan kemampuan intelektual namun lebih jauh adalah kemampuan untuk mengembangkan potensi spiritual dan emosional. Utari (dalam Sari, 2017) menyebutkan bahwa dalam taksonomi Bloom terdapat suatu hierarki yang mengidentifikasi skills mulai dari tingkat terendah sampai tertinggi, setiap tingkatan memiliki korelasi baik itu dari ranah kognitif, afektif dan psikomotorik. Ini menandakan bahwa dalam proses pendidikan, pengembangan ranah kognitif sebagai ranah pengetahuan atau intelektualitas juga harus diseimbangkan dengan pengembangan ranah afektif yaitu sikap baik itu sikap spiritual maupun emosional sehingga nantinya akan berpengaruh kepada ranah psikomotorik yaitu bertindak.

Tujuan dari keseimbangan tiga ranah tersebut adalah terbentuknya karakter yang mengarah kepada kecerdasan spiritual keagamaan. Tentu ada dua aspek yang mendasar yaitu kecerdasan dan spiritual, sehingga disini agama menjadi titik temu. Kecerdasan spiritual ini adalah untuk mengarahkan bagaiman individu dapat mengaplikasikan kecerdasannya kearah yang baik yang tidak bertentangan dengan norma-norma serta ajaran agama. Apalagi dalam ajaran agama Hindu tujuan utamannya adalah Mokshartam jagadhita ya ca iti dharmah dimana kebahagian sejati yang didapat melalui pelaksanaan ajaran dharma atau agama yang akan memberikan kebahagian yang sejati didunia ini yang nantinya agar dapat bersatu dengan brahman. Untuk mencapai tujuan tersebut maka dalam ajaran agama Hindu dikenal ajaran Catur Marga. (Jayendra, 2017) menjelaskan bahwa ajaran Catur Marga merupakan suatu metode atau cara yang dilakukan untuk mendekatkan diri kepada Tuhan Ida Shang Hyang Widhi Wasa melalui empat jalan. Sesuai dengan apa yang dijelaskan maka Catur Marga sebagai empat jalan atau metode didalamnya terdapat konsep bhakti marga, jnana marga, karma marga dan raja marga. Bhakti marga melalui jalan bhakti dengan metode melaksanakan upacara-upacara keagamaan, jnana marga adalah jalan mendekatkan diri kepada Tuhan melalui penyebaran ajaran-ajaran ilmu pengetahuan suci, karma marga melalui jalan berbuat baik tanpa pamerih dan raja yoga marga melalui jalan yoga samadhi untuk menyatukan diri 
dengan brahman. Maka dalam geguritan candrabherawa ajaran Catur Marga ini tertuang dalam teks yang tertulis sebagai berikut :

Olas asih sayangè ring sarwwa bhuta, mänuşa yajña uttami, to patut limbakang, rèh Ida Hyang Parama Buddha, nguhub sadaginging bhumi, sayang ring anak, sat bhakti ring Sang Hyang Widhi (Geguritan candrabherawa, pupuh durma, pada : 12, hal 14).

Terjemahannya :

Welas asih sayang kepada semua mahkluk, manusa yandnya utama, itu patut menjadi pedoman, kepada Tuhan, yang menciptakan isi dunia, sayang kepada anak, dan sujud bhakti kepada Ida Sang Hyang Widhi.

Pitra yajña bhaktinè těkèn kawitan, nu ñěněng anakè lingsir, ayahin dabdabang, haturin sandang pangan, mangda siddha ngalèdangin, ènto kinucap, pitra yajñanè uttami (Geguritan candrabherawa, pupuh durma, pada : 13, hal 14-15) Terjemahannya :

Pitra yajna bhakti kepada leluhur, kepada orang tua yang masih hidup, bantu dan mengabdi, berikan makanan, pakaian, supaya diberikan kebahagian, itulah adanya, ajaran pitra yajna yang utama.

Hěda pisan masolah hanè durśila, ngawè sěpung anak lingsir, solahè suśila, anggon mañěmbah kawitan, ngawangiyang anak lingsir, to makāwanan, ñumbah baan kuwangi (Geguritan candrabherawa, pupuh durma, pada : 14, hal 15)

Terjemahannya :

Jangan sekali berani bertindak yang durhaka, membuat orang tua marah, tingakh laku yang baik, untuk menyembah leluhur, menghormati orang tua, itu sebabnya, menyembah dengan kewangen.

Liyu pisan pidabdabe yan bawosang, indike ngastiti Widhi, ada karmma yoga, Ada jnana yoga tatujone wantah tunggil, nununge bhina, sami mauttama luwih (Geguritan candrabherawa, pupuh durma, pada : 15, hal 15)

Terjemahannya :

Banyak sekali yang patut dijelaskan, jika berdiskusi tentang memuja Hyang Widhi, ada Karma Yoga, Ada Jnana Yoga, tujuannya hanya satu, jalan yang beda, semua baik dan utama.

Jalan nè jani kawitin, bibitè mělah samběhang, sinah mělah hěntikannè, dwaning suba sinah pisan, bwina tong siddha lèmpasang, apa tandur kèto pupu, manut ucaping agama (Geguritan candrabherawa, pupuh Smarandana, pada : 25, hal 55).

Terjemahannya :

Mari kita mulai dari awal, bibit yang bagus ditanam, sehingga nanti bagus tumbuhnya, karena sudah demikian, tidak bisa dihindarkan, apa yang ditanam itu yang dipanen, sesuai dengan ajaran agama.

Minab suba titah Widhi, pacěpuk Kārmma Sanyaşa, lawan Yoga Sanyaşanè, rèh mula kapatut tunggal, tan siddha pacang sampūrnna, yan tan sami padha wruh, kadi Šiwa lawan Buddha (Geguritan candrabherawa, pupuh Smarandana, pada : 26, hal 55). 
Terjemahan bebasnya :

Mungkin sudah titah Hyang Widhi, bertemunya Karma Sanyasa dengan Yoga Sanyasa, semua memnag satu, tidak bisa sempurna, jika semua tidak mengetahi, bagaikan Siwa dan Buddha.

Kutipan teks diatas menjelaskan bagian-bagian dari Catur Marga yang masingmasing memiliki metode serta jalannya yang intinya bahwa walaupun jalan yang diambil berbeda namun tujuan dari jalan tersebut sama. Analogi sederhananya, sesorang yang ingin pergi ke suatu tempat yang sama namun menggunakan kendaraan yang berbeda, tentu pengalaman yang dialami oleh media sarana yang digunakan berbeda, namun tujuan yang diharapkan dan ingin dicapai sama. Terkait dengan pembentukan karakter kecerdasan spiritual kegamaan maka ajaran Catur Marga menjadi suatu pedoman bahwa setiap jalan yang dipilih dalam menuju Tuhan memiliki metode serta cara yang berbeda, namun jika Tuhan yang menjadi tujuan maka setiap perbedaan hanya sebuah bias yang memiliki tujuan yang sama. Maka proses internalisasi oleh lembaga pendidikan adalah dengan tetap memberikan pemahaman melalui transfer dan transformasi pengetahuan Catur Marga kepada peserta didik. Harus diberikan pemahaman pula bahwa setiap jalan akan memiliki pengalaman yang berbeda, sehingga tidak ada yang lebih sempurna, karena semua jalan saling melengkapi dan bermuara pada tujuan yang utama.

Lembaga pendidikan memiliki tanggung jawab penting dalam proses internalisasi dan penguatan karakter spiritual keagamaan. Donder (2006) menjelaskan bahwa anakanak atau para siswa masih murni dan merupakan pewaris kebenaran. Bahkan bukan hanya anak-anak dan para siswa saja, namun seluru manusia dan seluruh alam semesta berasal dari kebenaran (Donder, 2006). Ini menandakan bahwa sifat anak-anak dan para siswa yang murni dan seluruh manusia dan alam sesesta merupakan berasal dari kebenaran, sehingga lembaga pendidikan dan pelaku pendidikan memiliki tanggung jawab penting untuk tetap mengarahkan para peserta didik ini selalu dalam jalan kebenaran jalan dharma. Lembaga pendidikan juga harus selaing menyadari bahwa pendidikan tidak hanya berpusat pada satu lembaga saja, namun ketiga lembaga sebagai bagian dari trilogi pendidikan memiliki tanggung jawab yang sama dan memiliki beban yang sama yaitu membentuk dan mengembangkan peserta didik agar memiliki karakter mulia serta karakter spiritual keagamaan. 


\section{Kesimpulan}

Ajaran agama Hindu merupakan ajaran yang begitu kompleks, luas dan sangat suci. Dalam proses pelaksanannya tidak hanya dilakukan melalui upacara dengan berbagai upakaranya semata namun juga melalui berbagai cara. Dharma gita melalui sastra geguritan candrabherawa merupakan salah satu dari sekian banyak metode yang sering kali digunakan dalam proses pelaksanaan ajaran agama Hindu. Teks geguritan candrabherawa menyimpan berbagai ajaran suci Hindu yang termuat dalam bait-bait pada pupuh yang membentuknya. Berbagai ajaran suci Hindu seperti Tri Hita Karana, Tri Kaya Parisudha, Catur Varna dan Catur Marga memberikan gambaran begitu dalamnya kandungan ajaran suci hindu tersebut. Ajaran-ajaran suci inilah yang diharapkan dapat menjadi suatu acuan dan pedoman oleh setiap pelaku pendidikan dalam berbagai penguatan internalisasi nilai dalam pendidikan karakter sehingga dapat menjadi landasan serta pelindung dalam menanggulangi permasalahan demoralisasi yang sekarang cenderung menjadi momok dan masalah pendidikan. Implementasi ini tidak hanya pada ranah transfer pengetahuan namun harus ditransformasikan sehingga teori tidak hanya sekedar teori namun menjadi aplikasi. Jadi dapat disimpulkan bahwa teks geguritan candrabherawa merupakan sebuah karya sastra yang didalamnya mengandung berbagai ajaran suci Hindu yang dapat menjadi acuan dan pedoman nilai dalam proses internalisasi penguatan pendidikan karakter.

\section{Daftar Pustaka}

Aziz, F., Nurjanah, F., \& Sari, D. P. (2017). Aktualisasi TTB (Teori Taksonomi Bloom)Melalui Drama Kepahlawanan Guna Penanaman Pendidikan Karakter Pada Peserta Didik. FKIP e-Proceeding PBSI Universitas Jember, 715-724.

Donder, I. K. (2006). Sisya Sista Pedoman Menjadi Siswa Mulia. Surabaya: Paramita. Husamah. (2015). Pengantar Pendidikan. Malang: Umm Press.

Jalil, A. (2016). Karakter Pendidikan untuk Membentuk Pendidikan Karakter. Nadwa: Jurnal Pendiidkan Islam, 6(2), 175. https://doi.org/10.21580/nw.2012.6.2.586

Jayendra, P. S. (2017). AJARAN CATUR MARGA DALAM TINJAUAN KONSTRUKTIVISME DAN RELEVANSINYA DENGAN EMPAT PILAR PENDIDIKAN UNESCO. Sekolah Tinggi Pariwisata Bali (STPBI) Internasional Denpasar, (1), 73-84.

Madja, I. K. (2018). Landasan Pengembangan Etika Dan Moralitas Hindu. Guna Widya: Jurnal Pendidikan Hindu, 5(1), 67-78. https://doi.org/10.25078/gw.v5i1.613

Normina. (2017). Pendidikan dalam kebudayaan. Ittihad Jurnal Kopertais Wilayah XI Kalimantan, 15(28), 17-28.

Putu Sari, Ida Ayu \& Rudita, K. G. (2019). DHARMAGITA SEBAGAI TERAPI SENI KEAGAMAAN HINDU UNTUK DOSEN DAN MAHASISWA PADA UNIT KEGIATAN MAHASISWA. Widyanatya, 1(2), 112-127. 
https://doi.org/10.1017/CBO9781107415324.004

Rai, A. A. I., Dewi, M., \& Ganesha. (2014). PENGARUH MODEL VCT BERLANDASKAN KONSEP TRI KAYA SISWA KELAS V DI SD GUGUS III KECAMATAN SERIRIT 2013 / 2014. Jurnal Mimbar PGSD Universitas Pendidikan Ganesha, 02(01).

Rini, Y. S. (2010). pendidikan: Hakekat, Tujuan dan Proses. Jurnal Pendidikan, 1-13.

Setiawati, N. A. (2017). Pendidikan Karakter Sebagai Pilar Pembentukan Karakter Bangsa. Seminar Nasional Tahunan Fakultas Ilmu Sosial Universitas Negeri Medan, 1(1), 348-352.

Sudarsini, N. N., Vivekananda, A. And Sanstha, Y. (2018). Kasta Dan Warna: Sebuah Kritik Dalam Masyarakat Egaliter. Pangkaja: Jurnal Agama Hindu.

Sudarsini, N. N., Vivekananda, A., \& Sanstha, Y. (2018). Kasta dan warna: sebuah kritik dalam masyarakat egaliter. Pangkaja: Jurnal Agama Hindu.

Sumantri, M. S. (2015). Modul Hakikat Manusia Dan Pendidikan.

Tribunnews.com. (2020). Motif siswi SMP berinisial NF (15) tega menghabisi nyawa teman rumahnya dengan keji akhirnya terungkap. Diambil dari https://www.tribunnews.com/metropolitan/2020/03/08/terungkap-motif-abgbunuh-balita-dan-simpan-di-lemari-pelaku-semalaman-tidur-dekat-mayat-korban

UGM, F. (2020). Data UNICEF tahun 2016. Diambil dari UGM Website website: https://fk.ugm.ac.id/kekerasan-remaja-indonesia-mencapai-50-persen/

Utami, L. K. D. (2018). Kecerdasan Spiritual Sebagai Indikator Pen- Gukuran Keberhasilan Pelaksanaan Pendidi-. Guna Widya: Jurnal Pendidikan Hindu, 5(1), $17-32$. 